\title{
Combination of Aerobic and
}

Resistance Excercise in

\section{Lowering Blood Glucose Levels}

\section{Compared to Aerobic or}

\section{Resistance Excercises in a Male}

Wistar Rat Model with Diabetes

\section{Mellitus}

by Purwo Sri Rejeki

Submission date: 06-Feb-2020 09:58AM (UTC+0800)

Submission ID: 1252284242

File name: Excercises_in_a_Male_Wistar_Rat_Model_with_Diabetes_Mellitus.pdf (227.44K)

Word count: 3934

Character count: 21365 


\title{
Combination of Aerobic and Resistance Exercise in Lowering Blood Glucose Levels Compared to Aerobic or Resistance Exercises in a Male Wistar Rat Model with Diabetes Mellitus
}

\author{
Sahrul Latif ${ }^{1}$, Dwikora Novembri Utomo ${ }^{2}$, Purwo Sri Rejeki ${ }^{3}$ \\ ${ }^{I}$ Student of Magister Program of Sport and Health Science, Faculty of Medicine, University of Airlangga, Surabaya, \\ Indonesia \\ ${ }^{2}$ Department of Orthopedics and Traumatology, Faculty of Medicine, University of Airlangga, Surabaya, Indonesia \\ ${ }^{3}$ Department of Physiology, Faculty of Medicine, University of Airlangga, Surabaya, Indonesia, \\ \{kosambi_bante,dwikora_utomo,purwo_faal\}@yahoo.com,purwo-s-r@fk.unair.ac.id
}

\begin{abstract}
Keywords: Blood Glucose Levels, Aerobic Exercise, Resistance Training, Combination Exercises, Rat Model With Diabetic Mellitus.

Abstract: Diabetes mellitus (DM) is one of the biggest global health emergencies in the 21 st century. Exercise plays an important role in the prevention and management of type 2 diabetes because of its function in controlling blood glucose levels. This study aimed to compare the decrease of glucose levels as a result of aerobic, resistance and combination exercise in a male Wistar mice DM model. It was an experimental study with a pretest-posttest group design. A total of 33 male Wistar rats were divided into three groups; K1 (aerobic exercise), K2 (resistance training) and K3 (aerobic and resistance combination exercises). Glucose level data were collected before and after the treatment. The data of each group were processed using a paired ttest. Differences between groups were tested using One-Way ANOVA followed by Post Hoc with LSD. Mean glucose levels of K1 pre-test was $322.18 \pm 26.430 \mathrm{mg} / \mathrm{dL}$, post-test $117 / 36 \pm 19.946 \mathrm{mg} / \mathrm{dL}(\mathrm{p}<0.001)$, K2 pre-test $365.27 \pm 67.406 \mathrm{mg} / \mathrm{dL}, 3$ post-test $121.36 \pm 20.461 \mathrm{mg} / \mathrm{dL}$ ( $\mathrm{p}<0.001)$, K3 pre-test $394.64 \pm 73.992$ $\mathrm{mg} / \mathrm{dL}$, post-test $114.27 \pm 17.124 \mathrm{mg} / \mathrm{dL}(\mathrm{p}=0.001)$. Mean $\Delta$ blood glucose level in group K1 $(204.82 \pm$ $29.842) \mathrm{mg} / \mathrm{dL}, \mathrm{K} 2(243.91 \pm 60.907) \mathrm{mg} / \mathrm{dL}$ and $\mathrm{K} 3(280.36 \pm 29.924) \mathrm{mg} / \mathrm{dL}$. One-Way ANOVA test results showed $\mathrm{p}=0.013$ and the LSD test compared between $\mathrm{K} 1$ and $\mathrm{K} 2(\mathrm{p}=0.111), \mathrm{K} 1$ compared to $\mathrm{K} 3(\mathrm{p}=$ $0.003), K 2$ compared to $\mathrm{K} 3(\mathrm{p}=0.136)$. The three types of exercises (aerobic, resistance and combination) lowered the blood glucose levels. Comparison between the three types of exercises showed that combination exercise has better ability in lowering blood glucose levels compared to other exercises.
\end{abstract}

\section{INTRODUCTION}

Medical discovery and innovations against diabetes mellitus (DM) continue to grow and the number of adult patients is expected to increase faster than before (Danaei et al., 2011). Based on data from the International Diabetes Federation in 2015, the prevalence of diabetes mellitus is 1 in 11 adults and is expected to increase in 2040 to 1 in 10 adults. Riskesdas (Basic Health Research) results of the Ministry of Health of the Republic of Indonesia in 2013 showed that the proportion of diabetes mellitus in Indonesia is $6.9 \%$ with an estimated absolute number of 12 million people, while undiagnosed patients is estimated to be more than 8 million people. Personal health costs and public costs due to diabetes mellitus are quite high and are expected to double in the next 25 years, leading to an increase in the economic burden for patients and the healthcare system (Scobie, 2007; Huang et al., 2009). Lack of understanding of social and economic impacts is the biggest barrier to blood glucose control. Thus, the combination of diet, physical activity and formulating a prevention policy that suppresses the increase of type 2 diabetes mellitus is needed.

Exercise has an important role in the prevention and management of type 2 diabetes mellitus because of its ability to control blood glucose (Colberg et al., 2010). This type of combination exercise can improve the control of blood glucose greater than isolated exercise (Oliveira et al., 2012). Research combining aerobic exercise and resistance training (combination exercise) has proven to be more 
advantageous and better than the type of exercise modality (Colberg et al., 2010; Snowling and Hopkins, 2006). Simultaneous exercise between resistance and aerobic exercise resulted in disrupted adaptation. The genetic and molecular adaptation mechanisms induced by resistance and aerobic exercise are different, and each mode of activation of the exercise can suppress certain gene parts and cellular signaling pathways (Hawley, 2009). To this extent the effect of combination exercises performed separately when compared with aerobic exercise and resistance to control of blood glucose levels has not been elucidated.

Aerobic exercise activates the signal pathway of adenosine-monophosphate-activated protein kinase (AMPK)-p38, mitogen-activated protein kinase (MAPK), and the peroxisome proliferator-activated receptor-gamma co-activator (PGC)-1 axis. Activation of AMPK from aerobic exercise may inhibit the mTOR signal through the tuberous sclerosis complex (TSC) and suppress the induction of muscle protein synthesis in resistance exercise. While resistance exercise activates phosphatidylinositol 3-kinase (PI3-k), the target activation of rapamycin (mTOR) signifies a cascade to modulate protein synthesis levels or long-term (weeks to months) damage and muscle hypertrophy; thus, it is estimated that combination exercise which is done separately between aerobics and its combination will result in a decrease in glucose levels better than either aerobic or resistance exercise only (Snowling and Hopkins, 2006). This study aimed to prove that aerobic, resistance and combination exercises have the ability to lower blood glucose levels in a male Wistar rat model with diabetes mellitus, as well as compare the result of combination exercises and aerobic exercise as well as resistance training in lowering blood glucose levels.

\section{MATERIAL AND METHODS}

\subsection{Research design}

It was a laboratory experimental study with a pretest-posttest group design (Zainuddin, 2014). The subjects of this study were male Wistar rats, aged 810 weeks, weighing 100-200 grams and agile physical condition. The 33 rats were divided into three groups. K1 group was given aerobic exercise, $\mathrm{K} 2$ was given resistance training and $\mathrm{K} 3$ was given combination exercises. The study protocol was approved by the ethics committee of Dr. Soetomo
Teaching Hospital Surabaya, Indonesia on July 27, 2007 with the number $748-\mathrm{KE}$.

\subsection{Diabetes Mellitus Model}

Diabetes mellitus condition was induced through the provision of a high-fat diet and STZ injection. A high-fat diet with $29 \%$ fat content, $35 \%$ carbohydrate and $17 \%$ protein was given for 28 days. STZ injections of $27.5 \mathrm{mg} / \mathrm{kg}$ in a citrate buffer ( $\mathrm{pH} 4.3-4.5)$ were given as a single dose with a concentration of $22.4 \mathrm{mg} / \mathrm{ml}$ on day 29 (Rimbun., 2015). Hyperglycemic rats are rats with blood sugar levels of 180-500 mg/dL (Etuk, 2010).

\subsection{Aerobic Exercise}

Aerobic exercise was carried out with $3 \%$ weightbearing swimming of fasting weight, tied $5 \mathrm{~cm}$ from the tip of the tail. Exercise was given once a day and 3 times/week. The swimming time was $80 \%$ of the maximum swimming time.

\subsection{Resistance Exercise}

Resistance exercises were carried out with $9 \%$ weight-bearing swimming of fasting weight, tied 5 $\mathrm{cm}$ from the tip of the tail; exercises were performed in 3 sets with 3 repetitions of each set with the time for each set being 60 seconds. Exercise was given 1 times/day with the frequency of 3 times/week and done for 4 weeks. The swimming time was $80 \%$ of the maximum swimming time.

\subsection{Combination Exercise}

Combination exercise was done by combining aerobic exercise and resistance training in separate sessions. The aerobic exercise was given twice/week, while resistance training was given once/week for 4 weeks. The length of swimming time was $80 \%$ of the maximum swimming time (McArdle and Montoye, 1966).

\subsection{Blood Glucose Level}

Blood glucose measurements were taken from the rats' tails using an on-Call device plus blood glucose meter. Measurements were made one day pretreatment and one day post-treatment. 


\subsection{Data Analysis}

Data were analyzed using descriptive distribution, analyzed by a normality test, homogeneity test, and paired t-test to see the effect of treatment in the same group and the One-Way ANOVA test to ascertain the difference between the groups. It was then followed by Post Hoc Test using LSD. The data were analyzed using SPSS 20.0 for Windows.

\section{RESULT}

\subsection{Body Weight}

The smallest pretreatment weight was 105 grams and the largest was 181 grams. The smallest postadmission weight was 107 grams and the largest was 202 grams. The result details are shown in Table 1.

\subsection{Blood Glucose Level}

The lowest blood glucose levels after the high-fat diet and induced STZ (pre-exercise) was $292 \mathrm{mg} / \mathrm{dL}$ and the highest was $562 \mathrm{mg} / \mathrm{dL}$. The lowest postexercise blood glucose level was $71 \mathrm{mg} / \mathrm{dL}$ and the highest was $155 \mathrm{mg} / \mathrm{dL}$. The results are shown in Table 2 .

Based on the paired t-test, there were differences in pre-test and post-test glucose levels between groups $\mathrm{K} 1(\mathrm{p}=0.006), \mathrm{K} 2(\mathrm{p}=0.000)$ and $\mathrm{K} 3(\mathrm{p}=0.001)$ with all groups showing $\mathrm{p}<0.05$.

\subsection{Pre-test and post-test}

The delta of pretest and post-test glucose level data exhibited the lowest level of $157 \mathrm{mg} / \mathrm{dL}$ and the highest one of $426 \mathrm{mg} / \mathrm{dL}$. See Table 3 for details.

\section{DISCUSSION}

\subsection{The Effect of Aerobic Exercise on Blood Glucose Level}

K1 group shows that aerobic exercise can lower blood glucose levels in a male Wistar mice model with diabetes mellitus. The decrease in blood glucose levels due to aerobic exercise is similar to that of the research showing that aerobic exercise improves blood glucose control and decreases oxidative stress in type-2 diabetes mellitus (Nojima et al., 2008). Other studies revealed that aerobic exercise is beneficial for blood glucose control and blood glucose absorption as well as increased muscle insulin sensitivity (Colberg et al., 2010).

Several studies conducted based on different durations of aerobic exercise showed that short-term aerobic exercise decreases arterial stiffness in the carotid and femoral arteries by using ultrasound examination. This flexibility improvement is associated with amelioration of insulin resistance that affects the relationship between exercise and insulin resistance in skeletal muscle and arterial wall stiffness in type-2 DM (Yokoyama, 2003). Meanwhile moderate intensity aerobic exercise plays an important role in disrupting the normal development of diabetic peripheral neuropathy (DPN) in type-2 DM (Dixit et al., 2014).

The active mechanism of aerobic exercise in lowering blood glucose levels through activation of signaling pathways is involved in metabolic homeostasis, namely adenosine monophosphateactivated protein kinase (AMPK)-p38, mitogenactivated protein kinase (MAPK), and the peroxisome proliferator-activated receptor-gamma co-activator (PGC-1) axis. Aerobic exercise promotes muscle protein expression that can increase muscle capacity to increase glucose uptake in two ways. The first way is to inhibit the elements that interfere with the stimulus of insulin by increasing the capacity of beta-oxidation of fatty acids through increased mitochondrial density. The second way is by increasing the expression of GLUT4 and the insulin path component (Dos Santos et al., 2015).

\subsection{Effects of Resistance Exercises on Blood Glucose Level}

K2 group shows that resistance training can lower blood glucose levels in a male Wistar mice model with diabetes mellitus. The results of this study are similar to research where resistance training increased insulin sensitivity and glucose tolerance; therefore, it is very effective to improve overall metabolic health and reduce metabolic risk factors in DM patients (Strasser, 2013). Recent research suggests that resistance training is considered a future prescription for improving type 2 diabetes. This type of exercise is a promising strategy for promoting overall metabolic health in individuals with type $2 \mathrm{DM}$, through improved mitochondrial muscle performance and increased muscle mass that 
positively impacts the response to insulin and glucose control (Pesta, 2017).

The glucose clearance mechanism as a beneficial effect is due to stimulation of glycogen synthesis resistance training by inhibition of glycogen synthase kinase $3 \beta$ (GSK3) by AKT. GSK $3 \beta$ regulates the storage of glucose in the form of glycogen. AKT inhibits GSK3 by phosphorylating serine residues (Ser9 in GSK3). GSK3 inhibition increases the activation of glycogen synthase that contributes to glycogen stimulation. Glycogen synthase is an enzyme responsible for catalyzing the $\alpha(1 \rightarrow 4)$ relationship in glycogen formation in nonoxidative glucose removal. The increased activity of AKT-mediated glycogen synthase is a form of adaptation of glucose control in response to resistance training (Case et al., 2011).

Table 1: Mean and delta of pre-test and post-test weight gain

\begin{tabular}{|c|c|c|c|c|}
\hline \multirow[t]{2}{*}{ Group } & \multirow[t]{2}{*}{$\mathrm{n}$} & \multicolumn{2}{|c|}{ Weight (gram) } & \multirow{2}{*}{$\begin{array}{c}\Delta \text { weight (gram) } \\
\text { Mean } \pm \text { SD }\end{array}$} \\
\hline & & $\begin{array}{c}\text { Pretest } \\
\text { Mean } \pm \text { SD }\end{array}$ & $\begin{array}{c}\text { Post-test } \\
\text { Mean } \pm \text { SD }\end{array}$ & \\
\hline K1 & 11 & $153.00 \pm 20.746$ & $162.64 \pm 23.775$ & $-9.636 \pm 9.287$ \\
\hline K2 & 11 & $144.00 \pm 22.974$ & $150.55 \pm 22.518$ & $-6.545 \pm 3.857$ \\
\hline K3 & 11 & $147.55 \pm 13.772$ & $150.55 \pm 22.518$ & $-5.455 \pm 4.156$ \\
\hline
\end{tabular}

Table 2: Mean and delta of pre-test and post-test weight gain

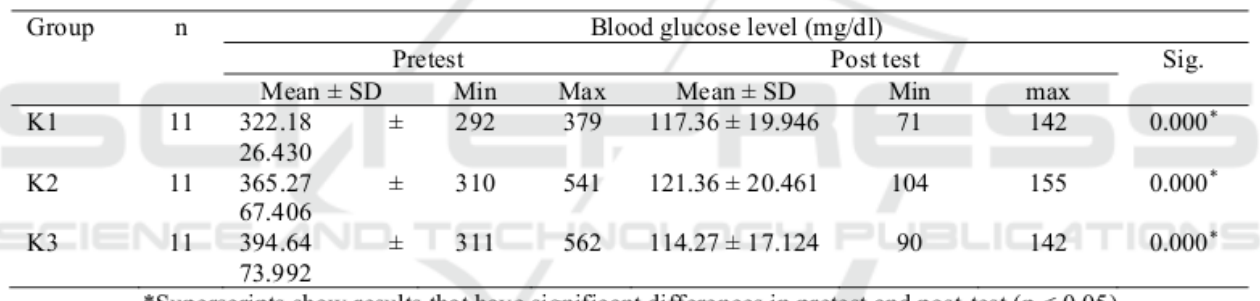

*Superscripts show results that have significant differences in pretest and post-test $(\mathrm{p}<0.05)$

Table 3. Mean and delta of pre-test and post-test weight gain

\begin{tabular}{ccccc}
\hline Group & $\mathrm{n}$ & $\begin{array}{c}\text { Mean } \Delta \text { Blood Glucose Level }(\mathrm{mg} / \mathrm{dL}) \\
\text { Mean } \pm \text { SD }\end{array}$ & Minimum & Maximum \\
\hline K1 & 11 & $(204.82 \pm 29.842)^{\mathrm{a}}$ & 157 & 244 \\
K2 & 11 & $(243.91 \pm 60.907)^{\mathrm{a}, \mathrm{b}}$ & 167 & 399 \\
K3 & 11 & $(280.36 \pm 29.924)^{\mathrm{b}, \mathrm{c}}$ & 180 & 426 \\
\hline
\end{tabular}

*Superscripts show result that have significant differences in pretest and post-test $(\mathrm{p}<0.05)$

\subsection{The Effect of Combination Exercises on Blood Glucose Levels}

K3 group shows that combination exercises can lower blood glucose levels in a male mice Wistar model with diabetes mellitus. These results are similar to those stating that combined exercise is an effective exercise method for improving functional capacity, body fat mass, strength and blood glucose control in people with type 2 DM (Maiorana et al., 2002)
A Randomized Controlled Trial conducted a combination of aerobic exercise and resistance training compared with the control group without exercise resulted in improved $\mathrm{HbAlc}$ levels in type $2 \mathrm{DM}$ patients. However, this cannot be achieved by either aerobic or resistance exercise only (Church et al., 2010). This is in line with the opinion that a combination of resistance and aerobic exercise regimens increases the control of glucose greater than aerobic exercise or resistance training intervention alone (Oliveira et al., 2012). 
Combination exercises in this study were conducted at different times because the research conducted showed that simultaneous exercise comprising resistance and aerobic exercise resulted in disrupted adaptation, compared to one exercise mode only. The genetic and molecular adaptation mechanisms induced by resistance and aerobic exercise are different with each activation mode of the exercise suppressing certain gene parts and cellular signaling pathways. Resistance training induces increased activity of the phosphatidylinositol 3-kinase (PI3-k)-Akt-activation target of rapamycin (mTOR) which signifies a cascade to modulate the rate of protein synthesis or long-term damage and muscle hypertrophy. Aerobic exercise activates signaling pathways involved in metabolic homeostasis, consisting of adenosine monophosphate-activated protein kinase (AMPK)p38, mitogen-activated protein kinase (MAPK), and the peroxisome proliferator-activated receptorgamma co-activator (PGC)-1 axis. Activation of AMPK from aerobic exercise can inhibit the mTOR signal through the tuberous sclerosis complex (TSC) and suppress the induction of muscle protein synthesis in resistance exercise (Hawley, 2009).

\subsection{Comparison of Glucose Levels In Aerobic, Resistance and Combination Exercises}

After the training period, all types of exercise (aerobic, resistance and combination) can lower the blood glucose levels in animal models with diabetes mellitus. The lowering in blood glucose levels was greatest due to the combination exercises, whereas the lowest blood glucose levels resulted from aerobic exercise. The aerobic exercise and resistance training exercises did not differ, and nor did the resistance exercise and combination exercise. Different results were obtained in aerobic exercise and combination exercises. This suggests that combination exercises are better than aerobic exercise in lowering blood glucose levels.

Aerobic exercise causes GLUT4 translocation to the cell surface and increased glucose transport (Zierath and Hawley, 2004; Sakamoto, 2002). Resistance exercise induces the response of hypertrophy and a shift in the type of muscle fibers in muscle exercises, which leads to increased utilization of whole-body glucose (Marcus et al., 2008).

Combination exercises performed in separate sessions are very advantageous because they induce two pathways that do not cause disrupted adaptation.
Adaptation of chronic aerobic exercise improves the performance capacity, while mitochondrial biogenesis is a result of activation of specific gene transcription during and after a single exercise. The adaptation form chronic resistance of induced exercise from is muscle hypertrophy occurrence in response to the coordination of genes and molecules that promote the enlargement of pre-existing muscle cells through the incorporation and addition of myonuclei (Fluck and Hoppeler, 2003).

The short study period (four weeks) in this study may be one of the causes of no significant difference found between the treatment of $\mathrm{K} 1$ and $\mathrm{K} 2$, treatment of $\mathrm{K} 2$ and $\mathrm{K} 3$. Aerobic exercise can increase steady-state mitochondrial protein content by $50-100 \%$ within 6 weeks. The mean half-life of protein turnover $\approx 5-7$ days indicates that stimulation by repetitive exercise is necessary to maintain increased mitochondrial content (Zierath and Hawley, 2004). While acute resistance training increases the turnover of skeletal muscle protein up to 48 hours after completion of exercise, either involving concentric or eccentric contractions, both are effective in increasing the turnover of these muscle proteins (Phillips et al., 1997).

\section{CONCLUSION}

Aerobic, resistance and combination exercises can lower blood glucose levels. Comparison of the three types of exercise shows that combination exercises give a better result than aerobic exercise in lowering blood glucose levels. In the future, combination exercises can be used as a procedure for regulating glucose levels in type 2 diabetes mellitus.

\section{REFERENCES}

CASE, N., THOMAS, J., SEN, B., STYNER, M., XIE, Z., GALIOR, K. \& RUBIN, J. 2011. Mechanical regulation of glycogen synthase kinase 3beta (GSK3beta) in mesenchymal stem cells is dependent on Akt protein serine 473 phosphorylation via mTORC2 protein. J Biol Chem, 286, 39450-6.

CHURCH, T. S., BLAIR, S. N., COCREHAM, S., JOHANNSEN, N., JOHNSON, W., KRAMER, K., MIKUS, C. R., MYERS, V., NAUTA, M., RODARTE, R. Q., SPARKS, L., THOMPSON, A. \& EARNEST, C. P. 2010. Effects of aerobic and resistance training on hemoglobin Alc levels in patients with type 2 diabetes: a randomized controlled trial. JAMA, 304, 2253-62. 
COLBERG, S. R., SIGAL, R. J., FERNHALL, B. REGENSTEINER, J. G., BLISSMER, B. J., RUBIN, R. R., CHASAN-TABER, L., ALBRIGHT, A. L., BRAUN, B., AMERICAN COLLEGE OF SPORTS, M. \& AMERICAN DIABETES, A. 2010. Exercise and type 2 diabetes: the American College of Sports Medicine and the American Diabetes Association: joint position statement executive summary. Diabetes Care, 33, 2692-6.

DANAEI, G., FINUCANE, M. M., LU, Y., SINGH, G. M., COWAN, M. J., PACIOREK, C. J., LIN, J. K., FARZADFAR, F., KHANG, Y. H., STEVENS, G. A., RAO, M., ALI, M. K., RILEY, L. M., ROBINSON, C. A., EZZATI, M. \& GLOBAL BURDEN OF METABOLIC RISK FACTORS OF CHRONIC DISEASES COLLABORATING, G. 2011. National, regional, and global trends in fasting plasma glucose and diabetes prevalence since 1980: systematic analysis of health examination surveys and epidemiological studies with 370 country-years and 2.7 million participants. Lancet, 378, 31-40.

DIXIT, S., MAIYA, A. G. \& SHASTRY, B. A. 2014 Effect of aerobic exercise on peripheral nerve functions of population with diabetic peripheral neuropathy in type 2 diabetes: a single blind, parallel group randomized controlled trial. $J$ Diabetes Complications, 28, 332-9.

DOS SANTOS, J. M., MORELI, M. L., TEWARI, S. \& BENITE-RIBEIRO, S. A. 2015. The effect of exercise on skeletal muscle glucose uptake in type 2 diabetes: An epigenetic perspective. Metabolism, 64, 1619-28.

ETUK, E. U. 2010. Animals Models for Studying Diabetes Mellitus. Agric. Biol J.N. Am, 1, 130-134.

FLUCK, M. \& HOPPELER, H. 2003. Molecular basis of skeletal muscle plasticity-from gene to form and function. Rev Physiol Biochem Pharmacol, 146, 159216.

HAWLEY, J. A. 2009. Molecular responses to strength and endurance training: are they incompatible? Appl Physiol Nutr Metab, 34, 355-61.

HUANG, E. S., BASU, A., O'GRADY, M. \& CAPRETTA, J. C. 2009. Projecting the future diabetes population size and related costs for the U.S. Diabetes Care, 32, 2225-9.

MAIORANA, A., O'DRISCOLL, G., GOODMAN, C., TAYLOR, R. \& GREEN, D. 2002. Combined aerobic and resistance exercise improves glycemic control and fitness in type 2 diabetes. Diabetes Res Clin Pract, 56, 115-23.

MARCUS, R. L., SMITH, S., MORRELL, G., ADDISON, O., DIBBLE, L. E., WAHOFF-STICE, D. \& LASTAYO, P. C. 2008. Comparison of combined aerobic and high-force eccentric resistance exercise with aerobic exercise only for people with type 2 diabetes mellitus. Phys Ther, 88, 1345-54.

MCARDLE, W. D. \& MONTOYE, H. J. 1966. Reliability of exhaustive swimming in the laboratory rat. $J$ Appl Physiol, 21, 1431-4.
NOJIMA, H., WATANABE, H., YAMANE, K., KITAHARA, Y, SEKIKAWA, K., YAMAMOTO, H., YOKOYAMA, A., INAMIZU, T., ASAHARA, T., KOHNO, N. \& HIROSHIMA UNIVERSITY HEALTH PROMOTION STUDY, G. 2008. Effect of aerobic exercise training on oxidative stress in patients with type 2 diabetes mellitus. Metabolism, 57, 170-6.

OliVeIRA, C., SIMOES, M., CARVALHO, J. \& RIBEIRO, J. 2012. Combined exercise for people with type 2 diabetes mellitus: a systematic review. Diabetes Res Clin Pract, 98, 187-98.

PESTA, D. H., GONCALVES, R.L.S., MADIRAJU, A.K., STRASSER, B AND L.M. SPARKS. 2017. Review : Resistance Training To Improve Type 2 Diabetes: Working Toward a Prescription for the Future. Nutrition and Metabolism, 14, 24.

PHILLIPS, S. M., TIPTON, K. D., AARSLAND, A., WOLF, S. E. \& WOLFE, R. R. 1997. Mixed muscle protein synthesis and breakdown after resistance exercise in humans. Am J Physiol, 273, E99-107.

RIMBUN. 2015. Profil Glukosa Luas Pulau Langerhans dan Ekspresi Reseptor Insulin Otot pada Berbagai Model Diabetes Melitus Tipe 2. Thesis, Universitas Airlangga

SAKAMOTO, K. A. L. J. G. 2002. Exercise Effects on Muscle Insulin Signaling and Action Invited Review : Intracellular Signaling in Contracting Skeletal Muscle. J App Physiol, 93, 369-383.

SCOBIE, I. N. 2007. Atlas of Diabetes Mellitus, London, Informa Healthcare UK Ltd.

SNOWLING, N. J. \& HOPKINS, W. G. 2006. Effects of different modes of exercise training on glucose control and risk factors for complications in type 2 diabetic patients: a meta-analysis. Diabetes Care, 29, 2518-27.

STRASSER, B. A. D. P. 2013. Review Article Resistance Training for Diabetes Prevention and Therapy: Experimental Findings and Molecular Mechanisms. Hindawi, 2013, 8 .

YOKOYAMA, H., EMOTO,M., FUJWARA, S., MOTOYAMA, K., MORIOKA, K., KOYAMA, H., SHOJI, T., INABA, M AND Y. NISHIZAWA. 2003. Short-term Aerobic Exercise Improves Arterial Stiffness in Type 2 Diabetes. Elsevier. Diabetes Research and Clinical Practice, 65, 85-93.

ZAINUDDIN, M. 2014. Metodologi Penelitian : Kefarmasian dan Kesehatan, Surabaya, Airlangga University Press

ZIERATH, J. R. \& HAWLEY, J. A. 2004. Skeletal muscle fiber type: influence on contractile and metabolic properties. PLoS Biol, 2, e348. 
Combination of Aerobic and Resistance Excercise in Lowering Blood Glucose Levels Compared to Aerobic or Resistance Excercises in a Male Wistar Rat Model with Diabetes Mellitus

ORIGINALITY REPORT

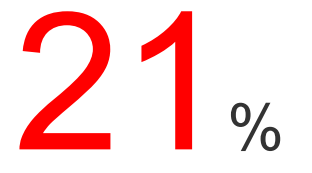

SIMILARITY INDEX
$15 \%$

INTERNET SOURCES
$15 \%$

PUBLICATIONS
$1 \%$

STUDENT PAPERS

PRIMARY SOURCES

1 www.ncbi.nlm.nih.gov Internet Source

2 Clarisse Noël A. Ayina, Jean Jacques N.

Noubiap, Laurent Serge Etoundi Ngoa, Philippe

Boudou et al. "Association of serum leptin and

adiponectin with anthropomorphic indices of

obesity, blood lipids and insulin resistance in a

Sub-Saharan African population", Lipids in

Health and Disease, 2016

Publication

3

Ratih Budinastiti, Henna Rya Sunoko, Nyoman Suci Widiastiti. "The Effect of Cloud Ear Fungus

(Auricularia polytricha) on Serum Total

Cholesterol, LDL And HDL Levels on Wistar

Rats Induced by Reused Cooking Oil", E3S Web

of Conferences, 2018

Publication 
5 eprints.umm.ac.id

6 theses.gla.ac.uk

7 Yokoyama, H.. "Short-term aerobic exercise improves arterial stiffness in type 2 diabetes",

Diabetes Research and Clinical Practice, 200408

Publication

8 Tina Agoestina, R.Hasan M Hoesni, Benny Hasan Purwara, Budi Iman Santoso et al.

"Randomized trial of one versus two

transcervical insertions of quinacrine pellets for

sterilization", Fertility and Sterility, 2002

Publication

9

Li-Jun Tan, Shan-Lin Liu, Shu-Feng Lei,

Christopher J. Papasian, Hong-Wen Deng.

"Molecular genetic studies of gene identification

for sarcopenia", Human Genetics, 2011

Publication

10 www.zora.uzh.ch Internet Source

11 mro.massey.ac.nz Internet Source

Oliveira, César, Mário Simões, Joana Carvalho, 
and José Ribeiro. "Combined exercise for

people with type 2 diabetes mellitus: A

systematic review", Diabetes Research and

Clinical Practice, 2012.

Publication

13

"Diabetes and Exercise", Springer Science and

Business Media LLC, 2018

Publication

14 www.oatext.com

Internet Source

15 "Diabetic Cardiomyopathy", Springer Nature, 2014

Publication

16

M. MIFTAHUSSURUR, S. SHIOTA, R. SUZUKI,

M. MATSUDA et al. " Identification of infection in

symptomatic patients in Surabaya, Indonesia, using five diagnostic tests ", Epidemiology and

Infection, 2014

Publication

17 researchbank.rmit.edu.au

Internet Source

18 A. R. Cooper, S. Sebire, A. A. Montgomery, T.

J. Peters, D. J. Sharp, N. Jackson, K.

Fitzsimons, C. M. Dayan, R. C. Andrews.

"Sedentary time, breaks in sedentary time and

metabolic variables in people with newly

diagnosed type 2 diabetes", Diabetologia, 2011 
19 www.spandidos-publications.com

20 diabetesalaska.com

Internet Source

21 baufachinformation.de

Internet Source

22 www.frontiersin.org

Internet Source

23 www.scielo.br

Internet Source

24 nutritionandmetabolism.biomedcentral.com Internet Source

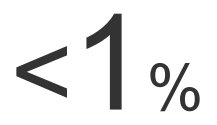

25 www.science.gov

Internet Source

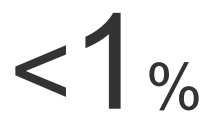

26 dspace.lboro.ac.uk Internet Source

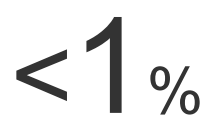

27 etheses.bham.ac.uk Internet Source

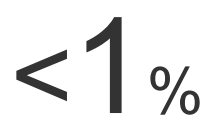

28 Submitted to iGroup

Student Paper

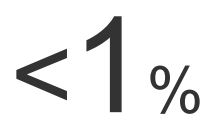

ajp.mums.ac.ir 
31 "Asian Oceanian Congress of Radiology 2012 and The Royal Australian and New Zealand College of Radiologists 63rd Annual Scientific Meeting : Oral Abstracts", Journal of Medical Imaging and Radiation Oncology, 2012. Publication

32 www.siditalia.it Internet Source

L. Deldicque, D. Theisen, M. Francaux.

"Regulation of mTOR by amino acids and resistance exercise in skeletal muscle", European Journal of Applied Physiology, 2005 Publication

34 purehost.bath.ac.uk Internet Source

35 www.peertechz.com Internet Source

36 canadiantaskforce.ca Internet Source

37 caribbean.scielo.org Internet Source 
39

"Posters", The Journal of Nutrition, Health and Aging, 2009

Publication

40 jama.jamanetwork.com Internet Source

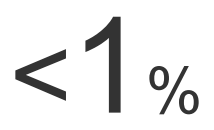

41

"Abstracts: Vascular Biology, XIIth International

Vascular Biology Meeting, 12-16 May, 2002,

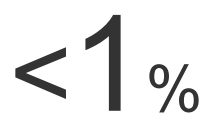

Karuizawa, Japan", Endothelium, 2009

Publication

42

"Abstracts : Abstracts", European Journal of

Heart Failure, 2014.

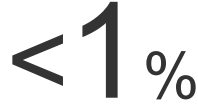

Publication

43

"Behavioral Diabetes", Springer Science and

Business Media LLC, 2020

Publication

Exclude quotes

On

Exclude matches

Off

Exclude bibliography

On 
Combination of Aerobic and Resistance Excercise in Lowering Blood Glucose Levels Compared to Aerobic or Resistance Excercises in a Male Wistar Rat Model with Diabetes Mellitus

GRADEMARK REPORT

FINAL GRADE

1100

\section{PAGE 1}

PAGE 2

PAGE 3

PAGE 4

PAGE 5

PAGE 6
GENERAL COMMENTS

Instructor 